\title{
Villous Adenoma
}

National Cancer Institute

\section{Source}

National Cancer Institute. Villous Adenoma. NCI Thesaurus. Code C7399.

An epithelial neoplasm morphologically characterized by the presence of a villous

architectural pattern. Most often it occurs in the large intestine, small intestine, and the stomach in which the neoplastic epithelial cells show dysplastic features. It may also arise in the urinary bladder, urethra, and vagina. 